\title{
STUDI SOLIDIFIKASI POLIETERSULFON DALAM PELARUT N-METIL-2- PIRROLIDON DENGAN ADITIV POLYVINYL PYRROLIDONE DAN 2- (METHACRYLOYLOXY) ETHYL PHOSPHORYL CHLOLINE
}

\author{
Nasrul Arahman*, Sri Aprilia, Teuku Maimun \\ Jurusan Teknik Kimia, Fakultas Teknik, Universitas Syiah Kuala \\ Jl. Tgk. Syech Abdurrauf 7 Darussalam Banda Aceh 23111, Indonesia \\ *Email : nasrular@unsyiah.ac.id
}

\begin{abstract}
Abstrak
Pada proses pembuatan membran melalui metode inverse fasa, morfologi membran yang dihasilkan ditentukan oleh besarnya konsentrasi polimer, pelarut dan non-pelarut. Pengetahuan dasar tentang komposisi yang sesuai dari masing-masing komponen tersebut diperlukan melalui penelitian penentuan titik embun larutan. Pada penelitian ini, studi terhadap penentuan titik embun telah dilakukan untuk mengetahui proses solidifikasi larutan polimer polyethersulfone (PES), polyinyl pyrrolidone PVP), dan 2(methacryloyloxy)ethyl phosphoryl chloline (MPC) didalam pelarut N-methyl-2-pirrolidon (NMP). Polimer yang bersifat hidrofilik PVP dan MPC digunakan sebagai membrane modifying agent (MMA) dalam rangka modifiaksi sifat permukaan membran. Dapat disimpulkan, penambahan PVP dan MPC ke dalam larutan polimer dapat mengurangi jumlah non-pelarut yang diperlukan untuk tercapainya kondisi cloud point dari larutan.
\end{abstract}

Kata kunci: Membran hidrofilik, titik embun, polimer aditiv, membran modfying agent.

\begin{abstract}
In membrane preparation process via phase inversion method, the morphology of fabricated membranes are determined by composition and concentration of polymer, solvent, and non-solvent. The basic knowledge of the appropriate composition of those components are needed by cloud point experiment. In this work, the study on cloud point experiment have been done to investigate the solidification process of polymer system of polyethersulfone (PES) and 2-(methacryloyloxy) ethyl phosphoryl chloline (MPC) in $N$-methyl-2-pirrolidon (NMP) via phase inversion technique. Hydrofilik polymer MPC were used as a membrane modifying agent (MMA) in order to modify the surface property of fabricated membrane. In sum, addition of PVP and MPC into polymer solution brought about reducing amount of non-solvent necessary to obtain the cloud point of solution.
\end{abstract}

Key word: hidrofilik membrane, cloud point, Polymeric additives, membran modfying agent.

\section{Pendahuluan}

Para peneliti dan industri pembuat membran saat ini terus mempelajari dan mengembangkan berbagai jenis membran dengan morfologi dan kinerja terbaik untuk diaplikasikan pada industri yang spesifik sesuai dengan sifat fisik dan kimia solute yang akan diolah. Aplikasi membran untuk proses yang berbeda dituntut untuk membuat dan memodifikasikan struktur pori yang berbeda pula. Membran dibuat dari berbagai jenis polimer dan sejumlah bahan aditiv yang berbeda sifat dicampur dalam larutan dop. Tujuannya adalah untuk memodifikasikan membran dengan menggunakan teknik tertentu sehingga diperoleh struktur membran dengan morfologi yang sesuai untuk aplikasi pada proses pemisahan tertentu. Polietersulfon (PES) adalah salah satu jenis polimer yang sangat populer digunakan sebagai material membran. PES mempunyai sifat mekanik yang baik, tahan terhadap temperatur tinggi mencapai $200{ }^{\circ} \mathrm{C}$, tahan terhadap klorin dan bahan kimia sensitif lainnya, juga mudah dibentuk modul dalam berbagai konfigurasi [13, 11].

Material membran telah berkembang pesat dan diaplikasikan secara luas dalam berbagai industri. Dalam industri pemisahan, membran telah digunakan untuk memisahkan ion dari senyawa kimia dalam larutan secara electrodialysis [10,6], dan memisahkan logam berat dan bakteri pathogen pada proses purifikasi air bersih [12,5]. Pada industri pengolahan minuman dan makanan, membran telah digunakan untuk pemurnian jus, pemekatan protein dan pemisahan komponen spesifik pada industri pemurnian minyak tumbuhtumbuhan [3]. Membran juga menjadi pilihan terbaik untuk pemisahan gas tertentu dari gas campuran [8]. Lebih jauh, membran sudah dikembangkan sebagai media pengantar tenaga (membrane fuel cell) [7], dan sebagai media pengantar suplemen tertentu (obat) kedalam tubuh manusia (drug delivery system) [4].

Telaah ilmiah untuk mendapatkan material membran yang memiliki morfologi dan kinerja 
yang spesifik adalah penting dilakukan. Pada pekerjaan ini dilakukan studi dasar bagaimana larutan polimer bisa membentuk membran (membrane solidified), berapa fraksi komposisi komponen polimer, pelarut, dan non-pelarut yang diperlukan, dan kapan titik beku (cloud point) larutan dapat tercapai.

Secara umum penelitian ini bertujuan untuk mengetahui konsep kompatibilitas membrane modfying agent (MMA) yaitu 2-(methacryloyloxy) ethyl phosphoryl chloline (MPC) terhadap polimer PES, menelaah proses solidifikasi dan pembentukan morfologi membran, serta mengkaji kondisi pembentukan cloud point dari larutan polimer. Lebih detail, penelitian difokuskan pada kajian dasar proses pemisahan phasa larutan polimer untuk pembentukan membran dari sistem tiga komponen yang terdiri dari polimer, pelarut, dan non-pelarut. Jumlah non-pelarut (air) yang dibutuhkan untuk terjadinya proses solidifkasi membran dipelajari berdasarkan uji titik beku (cloud point) larutan dengan kehadiran polimer yang bersifat hidrofilik.

\section{Metodologi Penelitian}

\section{Bahan dan Peralatan Penelitian}

Bahan utama yang digunakan berupa polimer Polietersulfon (PES, Ultrason E6020P, BASF), pelarut N-metil-2-pirrolidon (NMP), dan nonpelarut air. Dua jenis membrane mofying agent digunakan adalah (2-(methacryloyloxy)ethyl phosphoryl chloline) (MPC), polyvinylpirrolidon (PVP). Peralatan berupa 5 unit pelarut polimer, dan spektrofotometer untuk uji titik awan (cloud point).

\section{Uji Solidifikasi Sistem PES original}

Disiapkan tiga buah vial $100 \mathrm{ml}$ sebagai wadah untuk melarutkan polimer PES didalam pelarut NMP. Konsentrasi masing-masing komponen ditabulasikan pada Tabel 1. Larutan polimer diaduk lebih kurang selama tiga jam atau sampai polimer PES terlarut sempurna didalam NMP. Pengadukan dihentikan jika larutan mencapai titik homogen ditandai dengan warna larutan yang bening transparan. Larutan yang sudah homogen selanjutnya dicek absorbansi cahaya menggunakan spektrofotometer.

Selanjutnya kedalam larutan ditambahkan beberapa tetes non pelarut (air) untuk menguji apakah proses solidifikasi sudah terjadi. Berat tetesan air yang ditambahkan dicatat secara teliti sampai beberapa digit setelah tanda koma pada skala timbangan analitis. Sejumlah larutan polimer didalam vial akan membeku/mengeras pada saat air ditambahkan. Ini menunjukkan bahwa proses solidifikasi parsial telah terjadi, akibatnya larutan polimer tidak lagi homogen. Larutan diaduk lagi seperti proses awal sampai mencapai kondisi homogen dalam rentang waktu yang tidak bisa ditentukan. Saat larutan mencapai homogen, dilakukan lagi analisa absorbansi dengan spektrofotometer. Demikian seterusnya, kedalam larutan ditambahkan lagi tetes air, diaduk, dianalisa absorbansi secara berulang-ulang. Perlakuan baru dihentikan apabila larutan tidak bisa lagi mencapai kondisi homogen.

Tabel 1. Komposisi larutan polimer

\begin{tabular}{|c|l|l|l|l|}
\hline \multirow{2}{*}{ Sistem } & \multicolumn{4}{|c|}{ Komposisi (\% berat) } \\
\cline { 2 - 5 } & PES & PVP & MPC & NMP \\
\hline 1 & 20 & - & - & 80 \\
2 & 20 & 2 & - & 78 \\
3 & 20 & - & 2 & 78 \\
4 & 20 & 2 & 2 & 76 \\
\hline
\end{tabular}

\section{Uji Solidifikasi sistem PES+PVP.}

Pada sistem ini dilakukan penambahan aditif PVP terlebih dahulu kedalam sistem PES/NMP sebelum ditambahkan non-pelarut air. Konsentrasi masing-masing komponen diset sebagaimana ditabulasikan pada Tabel 1. Campuran tiga komponen tersebut diaduk sampai homogen, dianalisa absorbansi cahaya. Setelah itu ditambahkan non-pelarut air, diaduk lagi sampai homogen, dianalisa absorbansi cahaya, demikian seterusnya dilakukan pengulangan sampai percobaan dihentikan jika kondisi cloud point sudah tercapai.

\section{Uji Solidifikasi sistem PES+MPC.}

Tabel 1 juga memperlihatkan komposisi komponen polimer, aditiv, dan pelarut yang digunakan untuk system PES+MPC. Pada tahap ini dilakukan pengujian cloud point untuk sistem PES dengan jenis polymeric aditiv yang berbeda dari pengujian sebelumnya, yaitu menggunakan phospolipid polymer MPC. Konsentrasi masingmasing komponen diset sama dengan kondisi pembuatan sampel untuk uji solidifikasi pada system PES+PVP. Semua larutan diaduk sampai mencapai kondisi homogen, dan selanjutnya dilakukan uji cloud point sebagaimana prosedur yang telah dijelaskan pada uji solidifikasi system PES original.

\section{Uji Solidifikasi sistem gabungan}

Pengujian cloud point pada sistem ini dilakukan dengan menggabungkan dua jenis aditif yaitu PVP dan MPC kedalam polimer utama PES. Dilakukan pengujian cloud point dengan prosedur 
yang sama seperti sudah dijelaskan pada pengujian cloud point sistem PES original.

\section{Hasil dan Pembahasan}

\section{Solidifikasi larutan polimer}

Proses pelarutan polimer dalam pelarut NMP dilakukan dengan menggunakan wadah yang sama dan dengan total volume larutan yang sama untuk semua sistem. Proses pencampuran dilakukan dengan pengaduk stirrer pada skala $6 \mathrm{rpm}$ dan temperature ruangan $30{ }^{\circ} \mathrm{C}$. Proses homogenisasi larutan sebelum penambahan non-pelarut dapat tercapai dalam waktu rata-rata enam jam. Namun untuk memastikan larutan benar-benar sudah homogen, maka proses pelarutan dilakukan serentak selama 24 jam. Proses solidifikasi larutan polimer dapat tercapai setelah penambahan nonpelarut air murni dengan waktu pencampuran $2 \mathrm{x}$ 24 jam untuk semua sistem. Kondisi larutan polimer saat mencapai titik homogen dan titik solidifikasi (cloud point) ditandai dengan perubahan warna larutan dari warna bening transparan menjadi putih awan.

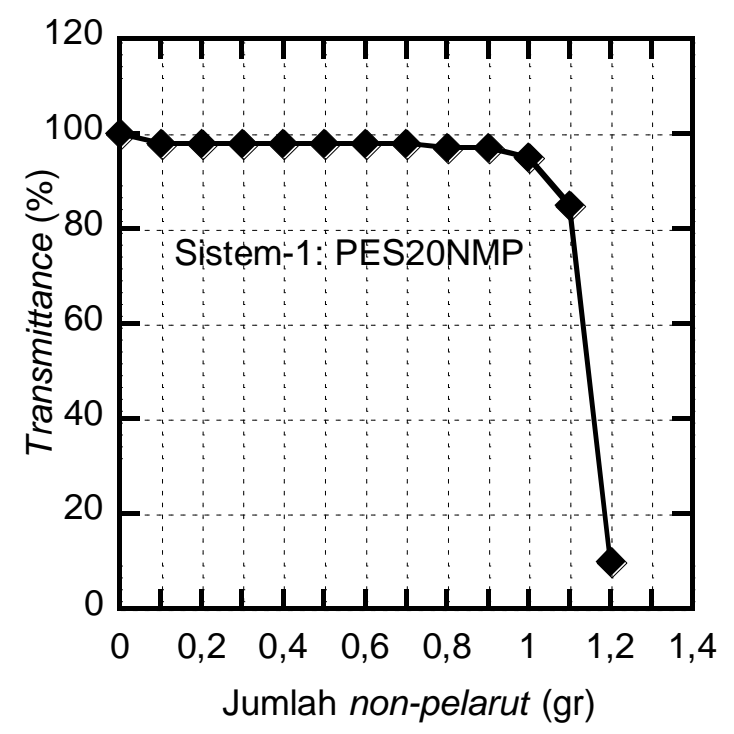

Gambar 1. Kebutuhan non-pelarut pada sistem-1 : PES20\% NMP80\%

\section{Kebutuhan non-pelarut untuk sistem polimer tunggal}

Pada proses pembuatan membran secara inversi phasa setidaknya dibutuhkan tiga komponen material agar larutan polimer dapat tersolidifkasi. Komponen tersebut adalah polimer sebagai material utama pembentuk membran, pelarut untuk melarutkan polimer, dan non-pelarut yang berfungsi untuk dapat terjadinya pemisahan fasa dan juga agar membran dapat tersolidifikasi dengan struktur tertentu. Ketiga komponen tersebut pada peneltiian ini digunakan secara berturut-turut PES, NMP, dan Air Murni. Pada proses pembuatan membran, komposisi dua koponen pertama (polimer dan pelarut) dapat ditentukan sesuai dengan kebutuhan karakteristik membran yang diharapkan berdasarkan uji coba.

Kebutuhan komponen ketiga (non-pelarut) secara alami mengikuti titik kesetimbangan tiga phasa dari larutan polimer. Artinya, jumlah nonpelarut yang dibutuhkan sesuai dengan jumlah polimer dan pelarut yang ada dalam larutan. Secara eksperimen, jumlah non-pelarut yang dibutuhkan dapat ditentukan melalui penelitian dasar penentuan komposisi tiga komponen dengan menguji titik embun (cloud point) larutan. Lebih lanjut, penentuan komposisi tiga komponen tersebut dapat digambarkan dalam bentuk diagram tiga fasa. Jumlah data non-pelarut air yang dibutuhkan untuk sistem larutan PES 20\% - NMP $80 \%$ dipaparkan pada Gambar 1. Proses solidifikasi larutan dapat tercapai dengan sempurna setelah penambahan air 1,2 gram.

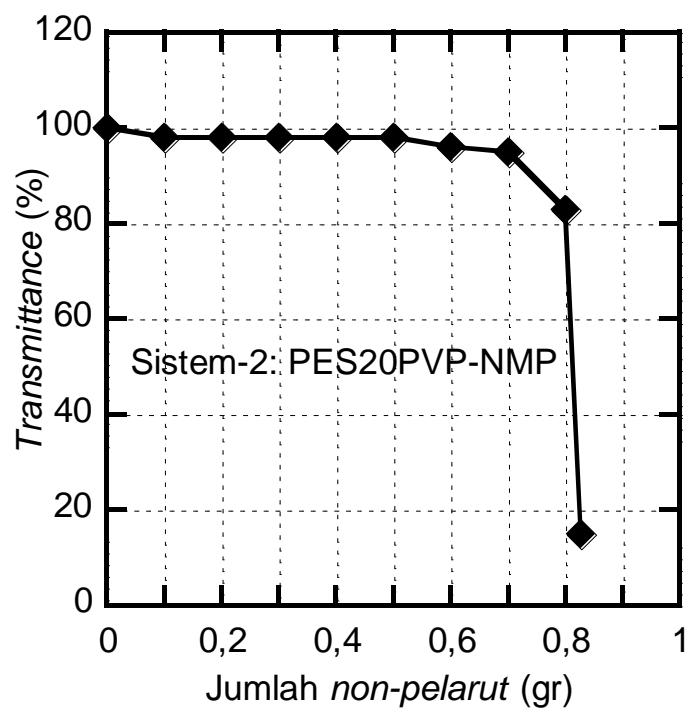

Gambar 2. Kebutuhan non-pelarut pada sistem2:PES20\%-PVP2\%-NMP78\%

Kebutuhan non-pelarut untuk sistem polimer dengan aditiv

Dalam industri pabrikasi membran sering ditambahkan polimer kedua (polymeric additives) untuk menciptakan membran dengan spesifikasi tertentu sesuai peruntukannya [2,9]. Kehadiran polimer kedua ini di dalam larutan polimer ikut mempengaruhi proses pencapaian kondisi pemisahan fasa dan proses solidifikasi membran. Kebutuhan non-pelarut air agar tercapainya kondisi pemisahan fasa dan terjadinya proses 
solidifikasi membran menurun dengan hadirnya polymeric additives PVP di dalam larutan polimer pada sistem 2 (Gambar 2). Demikian juga untuk kasus pada sistem 3 sebagaimana dipaparkan pada Gambar 3, jumlah non-pelarut air yang dibutuhkan menjadi berkurang dibandingkan dengan kondisi pada sistem 1 dengan tanpa aditiv.

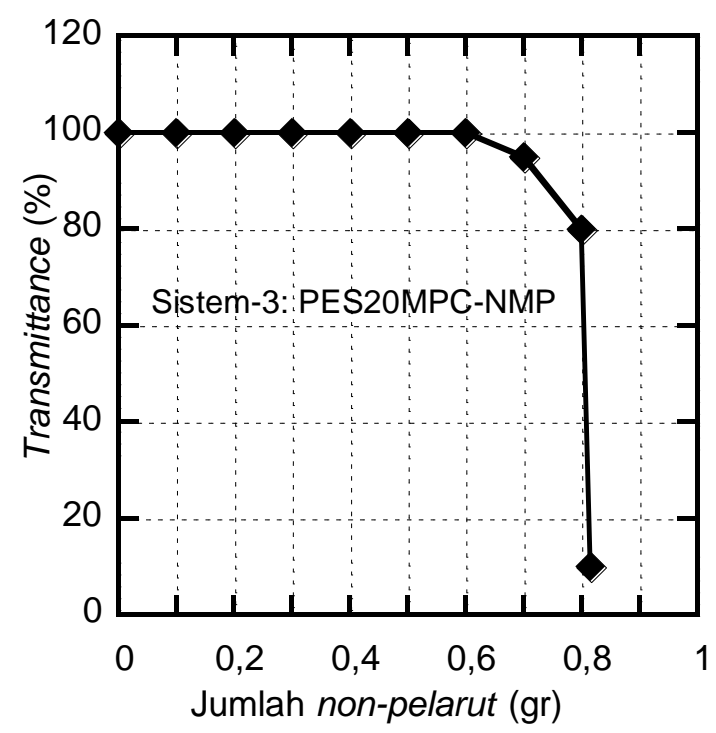

Gambar 3. Kebutuhan non-pelarut pada sistem-3: PES20\%-MPC2\% - NMP78\%

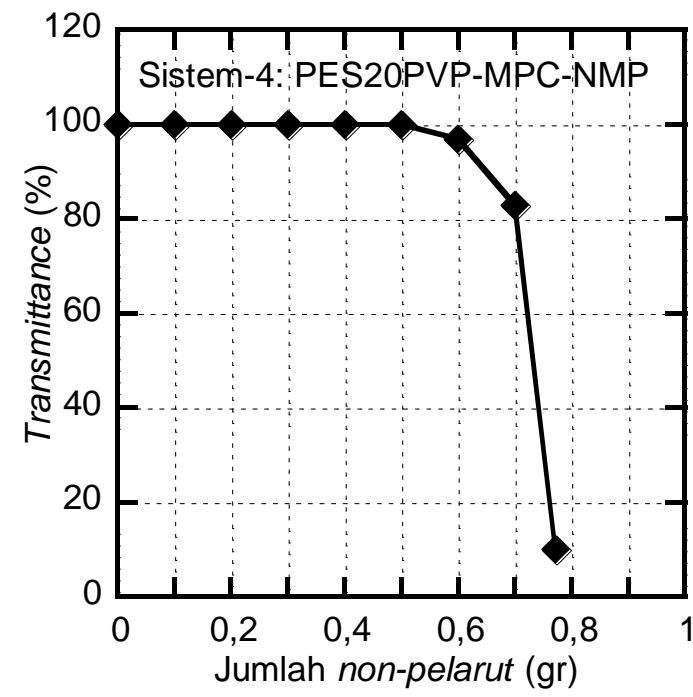

Gambar 4. Kebutuhan non-pelarut pada sistem-3: PES20\%-PVP2\%-MPC2\%-NMP76\%

Penambahan dua macam polymeric additive (PVP dan MPC) kedalam larutan polimer, menyebabkan jumlah non-pelarut yang dibutuhkan sistem semakin kecil (Gambar 4). Penambahan polymeric additives ke dalam sistem menyebabkan terjadinya peningkatan konsentrasi polimer. Proses pemisahan fasa dapat tercapai lebih cepat pada sistem dengan konsentrasi polimer tinggi, demikian sebaliknya proses solidifikasi membran akan lebih lambat pada sistem dengan konsentrasi polimer yang rendah [1].

Perbedaan jumlah non-pelarut yang dibutuhkan untuk tercapainya kondisi cloud point ini akan berpengaruh kepada struktur morfologi dan struktur pori yang terbentuk pada membran yang dihasilkan. Oleh karena itu, penambahan polymeric additive merupakan salah satu metode yang banyak dikembangkan oleh peneliti untuk meningkatkan kinerja membran. Lebih lanjut, system blending polymeric additive ini juga dapat digunakan untuk meningkatkan sifat hidrofilisitas membran.

\section{Penentuan cloud point}

Terbentuknya cloud point pada larutan polimer dapat diamati secara langsung dengan mata manusia. Dapat ditandai dengan perubahan warna larutan yang awalnya berwarna bening transparan menjadi berwarna putih awan. Jika ditambahkan non-pelarut air kedalam larutan polimer yang homogen, seketika larutan akan membeku pada sisi yang bersentuhan dengan air. Bila larutan yang membeku tadi dilarutkan lagi diikuti dengan pengadukan, maka larutan akan kembali homogen setelah mencapai waktu reaksi yang sesuai. Kondisi seperti ini menandakan bahwa kondisi cloud point belum tercapai pada larutan polimer tersebut. Penambahan non-pelarut air dilanjutkan lagi disertai pengadukan secara terus menerus. Pada suatu kondisi dengan jumlah air yang sesuai, lartuan polimer berubah warna dan tidak bisa tidak lagi mencapai homogen. Kondisi seperti inilah dinyatakan cloud point larutan sudah tercapai.

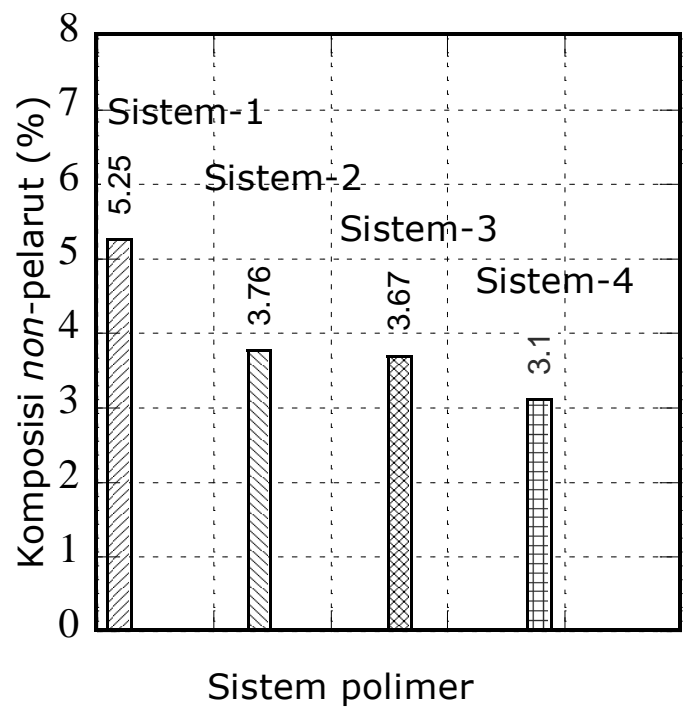

Gambar 5. Kebutuhan non-pelarut untuk tercapai cloud point. 
Gambar 5 memperlihatkan komposisi nonpelarut air yang dibutuhkan saat tecapainya cloud point untuk semua sistem larutan. Sebagai contoh, pada konsentrasi polimer PES $20 \%$ (sistem-1), cloud point dapat tercapai setelah penambahan non-pelarut air $5,52 \%$. Penambahan polymeric additive PVP kedalam sistem PES $20 \%$ menyebabkan jumlah non-pelarut air yang diperlukan semakin sedikit (sistem-2). Penambahan polymeric additive jenis MPC dapat memperkecil jumlah non-pelarut yang dibutuhkan sedikit lebih kecil dibandingkan pada penambahan PVP, yaitu 3,67 \% (Sistem-3). Jumlah non pelarut yang dibutuhkan semakin sedikit saat dua jenis aditiv ditambahkan ke dalam sistem (sistem-4). Hal ini karena totol konsentrasi polimer pada sistem-4 ini mengalami kenaikan karena penambahan $4 \%$ additive kedalam $20 \%$ polimer PES.

\section{Kesimpulan.}

Hasil penelitian studi solidifikasi larutan polimer yang telah dilakukan ini dapat memberikan informasi tentang konsep dasar penentuan komposisi larutan polimer untuk pembuatan membran secara inverse fasa. Konsentrasi polimer utama yang ditetapkan sangat berpengaruh pada proses pemisahan fasa larutan dan ikut menentukan jumlah non-pelarut yang diperlukan agar tercapainya kondisi cloud point. Pemberian polymeric additive PVP, dan MPC dapat memperkecil jumlah non-pelarut yang diperlukan untuk sistem dengan polimer utama PES 20\%. Secara keseluruhan untuk sistem yang diselidiki pada penelitian ini, kondisi cloud point dapat tercapai setelah penambahan non-pelarut berkisar antara $3-5,5 \%$ (berat).

\section{Ucapan Terimakasih}

Terimakasih kami sampaikan kepada Direktorat Jenderal pendidikan Tinggi (DIKTI), Kementerian Pendidikan dan Kebudayaan atas dukungan dana yang diberikan untuk pelaksanaan penelitian ini melalui Hibah Peneltian Fundamental tahun 2014.

\section{DAFTAR PUSTAKA}

[1] Arahman, N, Sotani, T, Matsuyama, H., "Effect of the addition of the surfacatant Tetronic 1307 on poly(ethersulfone) porous hollow fiber membrane formation, Journal of Applied Polymer Science, Vol 108, Hal. 3411-3418, 2007.

[2] Basri, H., Ismail, A.F., Aziz, M., "Polyethersulfone (PES)-silver composite UF membrane: Effect of silver loading and PVP molecular weight on membrane morphology and antibacterial activity", Desalination, Vol. 273, hal. 72-80, 2011.

[3] Coutinho, C.M., Chiu, M.C., Correa Basso, R.C., Ribeiro, A.P.B., Gonçalves, L.A.G., Viotto, L.A., State of art of the application of membrane technology to vegetable oils: A review, Food Research International, 42, 536550, 2009.

[4] Fujii, A., Ohmukai, Y., Maruyama, T., Sotani, T., Matsuyama, H., Preparation of DNA capsules cross-linked through NeutrAvidinbiotin interaction, Colloids Surf. A, 384, 529535, 2011.

[5] Huang, H., Young, T.A., Schwab, K.J., Jacangelo, J.G., Mechanisms of virus removal from secondary wastewater effluent by low Pressure membrane filtration, Journal of Membrane Science, 409-410, 1-8, 2012.

[6] Kabay, N., Arar, O., Samatya, S., Yuksel, U., Separation of fluoride from aqueous solution by electrodialysis: Effect of process parameters and other ionic species, Journal Of Hazardous Materials, 153, 107-113, 2008.

[7] Liang cui ; hisatani hitomi ; maruyama tatsuo ; ohmukai yoshikage ; sotani tomohiro ; matsuyama hideto, Influence of chemical compositions on the properties of random and multiblock sulfonated poly(arylene ether sulfone)-based proton-exchange membranes, Journal of Applied Polymer Science Vol. 116 pp. 267-279, 2009.

[8] Li, Y., Chung, T-S., "Highly selective sulfonated polyethersulfone (SPES)-based membranes with transition metal counterions for hydrogen recovery and natural gas separation", J. Membr. Sci, Vol. 308, Hal., 128-135, 2008.

[9] Loh, C.H., Wang, R., Shi, L., Fane, A.G., "Fabrication of high performance polyethersulfone UF hollow fiber membranes using amphiphilic Pluronic as pore-forming additives", J. Membr. Sci, Vol. 380, hal. 114- 123, 2011.

[10] Mulyati, S., Ohmukai, Y., Takagi, R., Matsuayama, H, "Improvement of the antifouling potential of an anion exchange membrane by surface modification with a polyelectrolyte for an electrodialyisis process", J. Membr. Sci Vol. 417-418, Hal. 137-143, 2012.

[11] Rahimpour, A., Madaeni, S.S., Mansourpanah, Y., "The effect of anionic, non-ionic and cationic surfactants on morphology and performance of polyethersulfone ultrafiltration membranes for milk concentration", J. Membr. Sci, Vol. 296, Hal. 110-121. 2007. 
[12] Saljoughi, E., dan , Mousavi, S.M., Preparation and characterization of novel polysulfone nanofiltration membranes for removal of cadmium from contaminated water, Separation and Purification Technology,90, 22-30, 2012.
[13] Wang, Y-Q., Su, Y-L., Sun, Q., Ma, X., Jiang., Z-Y., Improved permeation performance of Pluronic F127-polyethersulfone blend ultrafiltration membranes. J. Membr. Sci, Vol. 282, Hal. 44-51, 2006. 